\title{
Central bank communication, transparency and interest rate volatility: Evidence from the USA
}

\author{
Iris Biefang-Frisancho Mariscal and Peter Howells \\ School of Economics \\ University of the West of England
}

March 2007

\begin{abstract}
The FOMC has changed its way of communication twice, recently: from 2000-2003, the Committee imparted information about its assessment on the economic outlook (the balance-ofrisk statements) and since August 2003 the FOMC informs additionally about its outlook's implications on the future federal funds target rate (forward-looking language). The result should be that agents do not need to deduce FOMC's likely policy move on every twitch of central bank communication and macroeconomic news. Markets have anticipated FOMC policy decisions on the day of the meeting very well since 1994. Therefore, the focus of the paper is on the behaviour of market rates between FOMC meetings and on testing for greater 'smoothness' and lower volatility of market rates since 2000.

We apply an EGARCH model to forward rates at the short end of the yield curve. The model is used to test for the effects of the three disclosure regimes (pre-2000, 2000-2003, post2003) on the dependence of previous and current changes of the market rates in the conditional mean equation. It is expected to observe higher inertia during the periods when market participants are better informed.

Furthermore, generally, news increases interest rate volatility, since markets adjust interest rates in response to relevant news. However, other FOMC communication (other than the press statements after the FOMC meeting), may have a lower news value in the new disclosure regimes than it had in the pre-2000 period. Therefore, 'other' central bank communication may affect the volatility of interest rates differently in the three different regimes. This effect is tested for in the conditional variance of the regression model.

We find that there is evidence of differences in smoothness between the period until 2000 and the period of the balance-of-risk statement. Furthermore, we find that the effect of other than Fed press statements after FOMC meetings varies in the three periods. This is particularly so for Fed communication concerning economic outlook and speeches by the chairman of the Board.
\end{abstract}




\title{
Central bank communication, transparency and interest rate volatility: Evidence from the USA
}

\author{
Iris Biefang-Frisancho Mariscal and Peter Howells \\ University of the West of England
}

\section{Introduction}

The evidence of monetary policy transparency drawn from money market data is based largely on the behaviour of market rates (of various maturities) on the day of an interest rate decision. A significant reaction is termed a 'surprise' and is evidence of a lack of transparency. Generally speaking, such evidence suggests that most central bank interest rate decisions are well anticipated (for the US, for instance, Poole and Rasche (2000), Lange et al (2003), and Demiralp and Jorda (2004)). This paper moves the debate on by seeing what, if anything, 'openness' means for the behaviour of market interest rates between decision dates.

The motivation for this is threefold. Firstly, if a central bank has a target for short-term market rates which it sets at discrete intervals, it is reasonable to suppose that it would like market rates to reflect the target rate on a day-to-day basis for the inter-decision period. It is precisely this desire - to keep the overnight rate close to the official rate - that led the Bank of England to make fundamental changes to its operating procedures in April 2006 (Gorain, 2005).

Secondly, where the central bank is releasing 'forward-looking' information regarding the likely future path of interest rates it presumably wishes that information to be taken seriously by markets.

Thirdly, if the release of forward-looking information has any impact on financial markets, then we would expect it to be revealed in a reduction of uncertainty about the next policy-rate change between decision dates and we should expect the path of money market rates to reflect more accurately the rate theoretically implied by the previous and the next expected official decision.

Fourthly, in the last few years the Federal Open Markets Committee (FOMC) has modified its information releases in ways that have given progressively increasing attention to the future outlook and should, therefore, have had a marked effect on inter-meeting interest rate volatility. For example, since the beginning of 2000, the FOMC began releasing a press statement after every meeting which described the current state of the economy and, in a somewhat formulaic description, the so called 'balance-of-risk', with respect to inflationary pressures and economic conditions in the foreseeable future. The 'balance-of-risk' part of the 
statement also provided information about the likely course of monetary policy, but it did so indirectly by describing the Committee's assessment of the potential risks to its two objectives, high sustainable employment and price stability. Since August 2003, the FOMC has become more explicit, by commenting on the policy rate, and its likely future evolution, directly. Since then, the statements convey information to the markets about the FOMC's economic outlook and its policy approach. By additionally releasing information of near-term policy implications, the Committee is surrendering an information advantage which it previously enjoyed over private agents. As a consequence, those agents may more heavily base their judgment on future policy moves by FOMC on the Committee's press statements after the meeting than on its other communications (as agents under the BoE regime, for instance, need to do). Consequently, the pricing of financial instruments will be different under the three regimes.

The paper is organized as follows: In Section 2, we describe the changes in disclosure practice and institutional settings at the Federal Reserve between February 1994, when the FOMC first began to release a press statement describing its policy action and March 2006. In section 3, we are concerned to find out whether agents' expectations have been influenced by the most recent changes in FOMC’s communication. Since August 2003, the FOMC has introduced 'forward looking' language in its press release. This phrasing is used to suggest the probable direction of the federal funds target rate in the next and subsequent meetings. We begin by examining some graphs which display the change in the forward rates of certificates of deposit on days of FOMC meetings, a change on the day suggesting a degree of surprise and therefore of a lack of transparency. We find, in line with a number of other studies, that over the sample period, 1994-2006, changes in (short-term) market rates on FOMC meeting days are negligible and that this is unchanged in the period since August 2003.

In section 4, we turn to the major innovation of this paper, namely the hypothesis that market rate adjustments should be smoother in the post-2003 period. We give some theoretical reasons and we provide some indicative empirical evidence.

In section 5, we test whether market interest rate volatility has changed over the period, applying an exponential GARCH model. If ‘balance-of-risk' and 'forward looking' language indicate to agents the likely policy outcome of future FOMC meetings then, under this regime, market rate volatility should be lower between meetings than it was before 2000. Further, we expect that previous day market rate changes have on average a greater effect on today's change in the later periods than in the pre-2000 period. We find that inertia is higher for the 'balance-ofrisk' period than for the period before. Additionally, there is evidence that Fed communication effects on volatility differ between regimes. However, there is no unique evidence that the 
information content of other (than Fed press statements after FOMC meetings) has fallen over time.

Section 6 summarizes and concludes.

\section{Communication at the Fed}

A key date in Fed disclosure practice is February 1994, when the FOMC began to announce its target federal funds rate on the day of the meeting. Previously, markets needed to infer the intended rate from the type and size of its open market operations until, at a subsequent meeting, the decision by the FOMC was published. There is substantial evidence that this change in procedure improved markets' understanding of Fed policy. For instance, Poole and Rasche (2000), Lange et al (2003), and Demiralp and Jorda (2004) find that since 1994, the announcement of the federal funds target rate and the FOMC meeting schedule improved markets' anticipation of the timing and nature of future policy moves. Lee (2002), shows that interest rate volatility has fallen in response to Fed announcements. Exceptionally, however, Bonfim and Reinhart (2000) did not find evidence that the change in disclosure policy over the period 5 years after 1994 by the Fed had a significant effect on price setting.

From May 1999, until February 2000, the FOMC began to issue a press statement immediately after every meeting at which there were either major shifts in the Committee's view about future economic development, or, when the Committee decided to change the policy rate. The public statement regarding shifts in the Committee's view on future economic development, was intended to inform the public quickly about FOMC's assessment and to provide an indication of the likelihood of a future rise or fall in the official interest rate. An example of such a statement communicating the shift in the FOMC's view is the press release on 18 May 1999. It says ' ...the Committee was concerned about the potential for a buildup of inflationary imbalances that could undermine the favorable performance of the economy and therefore adopted a directive that is tilted toward the possibility of a firming in the stance of monetary policy.' In the following meeting on $30^{\text {th }}$ June 1999, the policy rate was increased by 25 basis points.

\section{1 'Balance of risk' statements}

From February 2000 until May 2003, the FOMC used a different disclosure procedure (Federal Reserve Board, 2000). Firstly, the Committee determined that a press release was issued immediately after every meeting, regardless of whether monetary action was taken or whether there was a shift in the Committee's view on prospective developments. Further, the FOMC 
changed its language so that the statement indicated how the Committee assessed the risk of greater inflationary pressure or economic weakness in the foreseeable future. While under the previous procedure, the Committee's statement referred to the relative likelihood of a future increase or decrease in the federal funds rate, the new statement addressed a balance of risk to the target of price stability and economic growth. The language used to describe the FOMC’s judgement on the future development is pre-set: 'Against the background of its long-run goals of price stability and sustainable economic growth and of the information currently available, the Committee believes that the risks are [balanced with respect to prospects for both goals] [weighted mainly toward conditions that may generate heightened inflation pressures] [weighted mainly toward conditions that may generate economic weakness] in the foreseeable future.' (Federal Reserve Board, 2000, p. 2) Further, the Committee clarified that 'the foreseeable future' is meant to convey a horizon that extends beyond the next FOMC meeting.

\section{2 'Forward-looking' language}

In August 2003, the FOMC introduced a 'forward-looking' language into its post-meeting statements with the aim of conveying the probable direction of the federal funds target rate over the next one or more meetings. On $12^{\text {th }}$ August 2003, the statement read: ' ...In these circumstances, the Committee believes that policy accommodation can be maintained for a considerable period.' (Federal Reserve Press Release, 2003). The language was modified again in January 2004 to: '.. the Committee believes that it can be patient in removing its policy accommodation.' (Federal Reserve Press Release, 2004, January). These statements informed markets on FOMC economic outlook and policy approach. At the time, when the Committee used the phrase 'considerable period', strong economic growth in the third quarter of 2003 may have influenced markets to think that a rise in the policy rate was imminent and agents incorporated this expectation into prices. However, the FOMC believed that the strong growth was due to a sharp rise in labour productivity with little or no effect on inflationary pressure. At the same time, capacity utilisation and inflation were low, so that the Committee did not see any reason for raising rates as the market seemed to anticipate. The language of the statement in August 2003 and the following statement convinced markets that a tightening was not imminent and market rates at all maturities fell (Bernanke, 2004). In May 2004, the language changed to '...the Committee believes that policy accommodation can be removed at a pace that is likely to be measured.' (Federal Reserve Press Release, 2004, May) and in the subsequent meetings, the federal funds rate was raised by 25 basis points. The language changed again in December 2005 to: 'The Committee judges that some further measured policy firming is likely to be needed to 
keep the risks to the attainment of both sustainable economic growth and price stability roughly in balance.' (Federal Reserve Press Release, 2005, December), indicating that the FOMC intended to continue with a tightening of its policy.

\section{Preliminary analysis}

We use daily data over the period from February 1994 until June 2006. This period coincides with the time when FOMC began to release a press statement on its desired policy rate after every meeting at which the policy rate was changed. Also, as pointed out above, a major part of the literature found that this change in procedure was decisive.

We use the federal funds target rate as the FOMC policy rate and we calculate 1-month horizon (annualized) forward rates from spot yields of 1-, 3- and 6-month certificates of deposit. ${ }^{1}$ As a first step, we are interested in measuring the impact of policy announcements on interest rate expectations one month ahead for deposits over a 1, 3 and 6 month period. Relatively small responses of the (forward) market rates on the day of the day of the FOMC meeting would indicate that markets were anticipating policy announcements well and that the information content of the announcement was already, to a large extent, reflected in market prices.

Over the sample period, the FOMC met 97 times and changed the federal funds target rate 50 times. The policy rate changed only once by 75 basis points (in November 1994); it changed 13 times, (before January 2002), by 50 basis points and at all other times by 25 basis points. Unscheduled meetings were on the following dates: $18^{\text {th }}$ April $1994,15^{\text {th }}$ October $1998,3^{\text {rd }}$ January, 18th April and $17^{\text {th }}$ September 2001. At these meetings, the federal funds target rate changed by $25,-25,-50,-50$, and -50 basis points, respectively.

We estimate and discuss varying maturities, but for reasons of space we show graphs only of the 1-month forward rate, when the graphs of the other maturities are similar. Hence figures 1 and 2 show changes in forward rate in response to changes in the federal funds target rate and to no changes in the target rate, respectively. The green horizontal lines enclose the area in which the change in the interest rate was 5 basis points or less on the day on which the FOMC met. We interpret changes of 5 basis points or fewer as inevitable noise and consistent with a lack of surprise adjustment by money markets. The circles in figure 1 indicate that the target rate

\footnotetext{
${ }^{1}$ Haldane and Read (2000) also calculated one-month (annualized) forward rates, assuming a linear market yield curve between the observed spot yields in a similar exercise for the UK and the USA.
} 
changes were (absolute) 25 basis points, squares show (absolute) changes of 50 basis points or more and stars represent changes in the forward rate on unscheduled meetings. All the plots suggest that overall markets were very well able to anticipate changes as well as no changes in the official rate. Furthermore, there does not appear to be a great difference between the two regime periods, except for perhaps a closer clustering around the zero-line during the later period. In other words, it seems unlikely that anything since the reform in 1994 could have done much to improve markets' understanding if we judge only by the degree of surprise on the announcement day.

Figure 1: change in 1-month forward rate in response to change in FFTR

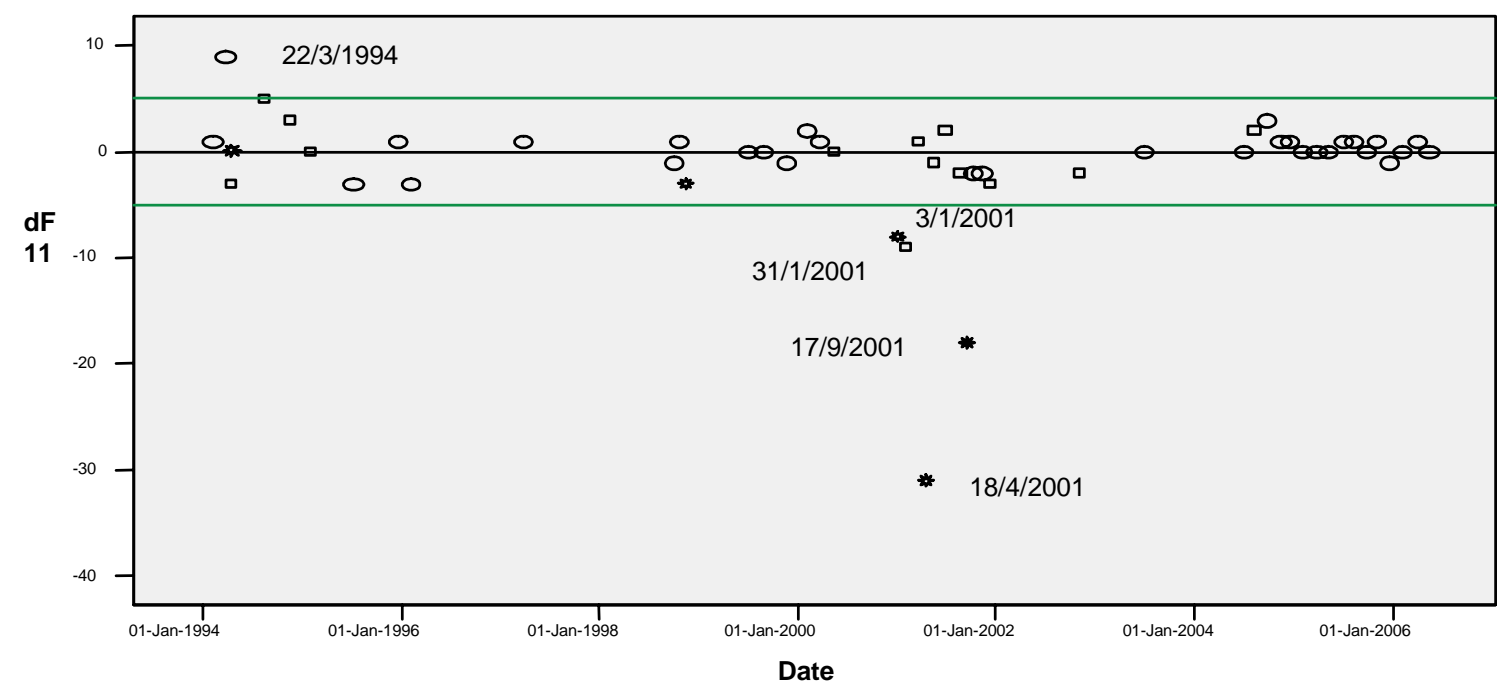

Furthermore, markets do not appear to have had greater difficulty in anticipating 'large' (50 bp) target rate changes on scheduled meetings than 'small' (25bp) changes. The only exception is the reduction in the federal funds target rate by 50 basis points at the end of January 2001. However, even then the adjustment on the day of announcement is rather low in relation to the overall change in the federal funds target rate.

Obviously, when the FOMC took action on days outside regularly scheduled meetings, markets could not predict target rate changes well. The greatest surprise occurred in April 2001, where the FOMC reduced the target rate by 50 basis points. The press release by the FOMC at the previous meeting in March pointed out that the Committee was concerned about the economic weakness in the foreseeable future and gave some indication that its interest rate may continue to fall in the future, but there was no clear indication that the Committee was to intervene earlier than at the planned next meeting '...the possibility that this excess [productive capacity] could continue for some time and the potential for weakness in global economic 
conditions suggest substantial risks that demand and production could remain soft. In these circumstances, when the economic situation could be evolving rapidly, the Federal Reserve will need to monitor developments closely.' (Federal Reserve Press Release, 2001, March).

Figure 2 shows the change of the market rate on days when the FOMC met and did not decide to change the target rate. There are few occasions when market rates adjusted by more than 5 basis points on the day of the policy announcement. On all other days, changes lie in between the green horizontal lines, indicating that markets did expect a continuation in FOMC policy.

Figure 2: changes in the 1-month forward rate when the FFT remained unchanged

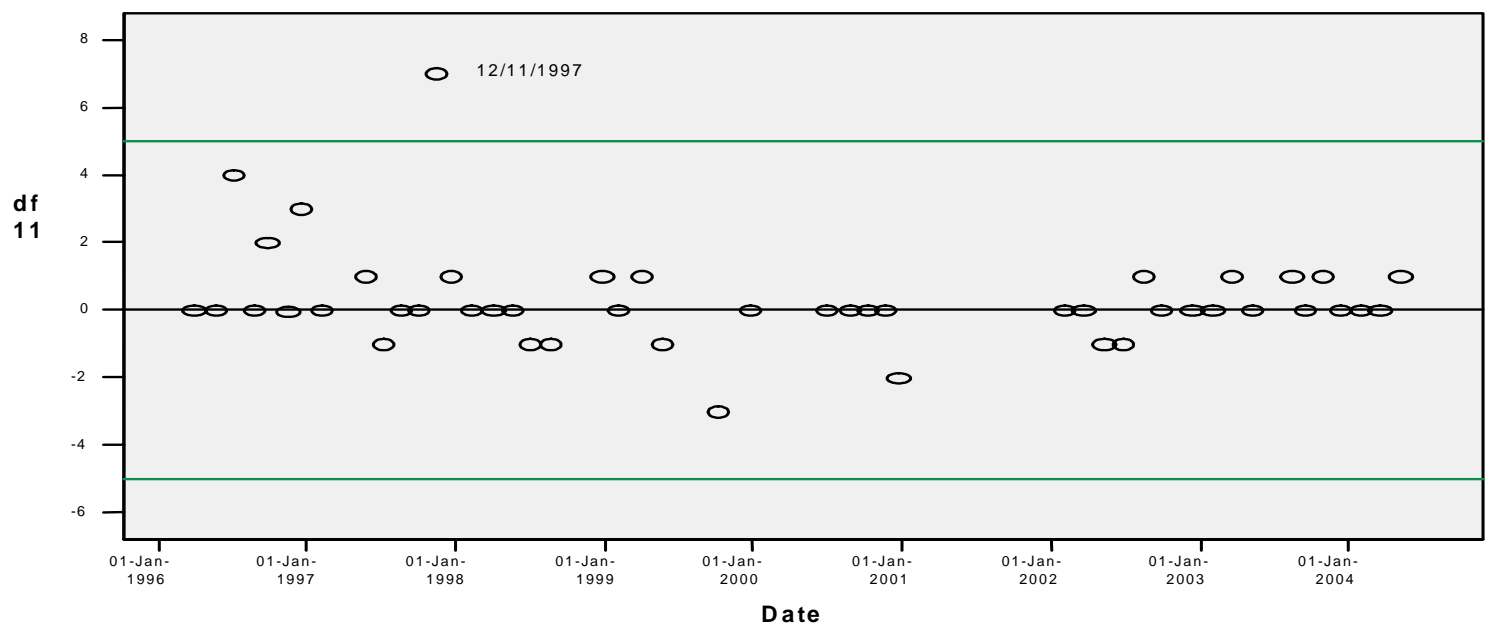

So far, we conclude that the graphs show that since 1994, markets have had no serious difficulty in anticipating FOMC policy decisions. It seems unlikely, therefore, that the change in the style of communication in 2003 could have had any effect on the average change in market rates on the day of FOMC policy announcement. Furthermore, the size of the target rate change does not seem to be important. The only time when markets were taken by surprise was on days of unscheduled meetings. On virtually all other occasions, future policy action seems to have been incorporated in market rates by the time of the announcement. 


\section{Market rate volatility between FOMC meetings}

Before we turn to discuss agents' pricing of instruments in the inter-meeting period, we first turn to the policy direction the FOMC gave in the two periods January 2000 until May 2003, and since August 2003. In this section, our main interest lies in the degree of coherence between FOMC’s announcements and policy actions. Clearly, investors will only change pricing behaviour, if the Committee's statements are credible. Table 1 compares the formulaic wordings of the 'balance of risk' period with the policy decision in the subsequent meeting.

Table 1: FOMC statements and subsequent policy action in the period January 2000 until June 2003.

\begin{tabular}{|c|c|c|}
\hline Date & $\begin{array}{c}\text { Announcement for } \\
\text { next meeting (and } \\
\text { beyond) }\end{array}$ & $\begin{array}{c}\text { Action next } \\
\text { meeting }\end{array}$ \\
\hline 2.2 .2000 & 2 & +25 \\
\hline 21.3 .2000 & 2 & +50 \\
\hline 16.5 .2000 & 2 & 0 \\
\hline 28.6 .2000 & 2 & 0 \\
\hline 22.8 .2000 & 2 & 0 \\
\hline 3.10 .2000 & 2 & 0 \\
\hline 15.11 .2000 & 2 & 0 \\
\hline 19.12 .2000 & 3 & -50 \\
\hline 3.1 .2001 & 3 & -50 \\
\hline 20.3 .2001 & 3 & -50 \\
\hline 18.4.2001 U & 3 & -50 \\
\hline 15.5 .2001 & 3 & -25 \\
\hline 27.6 .2001 & 3 & -25 \\
\hline 21.8 .2001 & 3 & -50 \\
\hline 17.9 .2001 & 3 & -50 \\
\hline 2.10 .2001 & 3 & -50 \\
\hline 6.11 .2001 & 3 & -25 \\
\hline 11.12.2001 & 3 & 0 \\
\hline 30.1 .2002 & 3 & 0 \\
\hline 19.3.2002 & 1 & 0 \\
\hline 7.5 .2002 & 1 & 0 \\
\hline 26.6 .2002 & 1 & 0 \\
\hline 13.8.2002 & 3 & 0 \\
\hline 24.9 .2002 & 3 & -50 \\
\hline 16.11 .2002 & 1 & 0 \\
\hline 10.12 .2002 & 1 & 0 \\
\hline 29.1.2003 & 1 & 0 \\
\hline 18.3.2003 & $*$ & 0 \\
\hline 6.3 .2003 & 3 & -25 \\
\hline 25.6 .2003 & 1 & 0 \\
\hline
\end{tabular}

Note: ' 1 ' stands for the formulation '...balanced with respect to prospects for both goals ...'; ' 2 ' is for the phrase '... weighted mainly toward conditions that may generate heightened inflation pressures...'; and ' 3 ' signifies the expression '.. . weighted mainly toward conditions that may generate economic weakness...' (see Federal Reserve Board, 2000) 
Table 1 shows that most of the time (73\%) the Committee followed its balance of risk assessment in the next meeting. There is no occasion where the Committee announced a potential tightening or easing and in the subsequent meeting reversed this decision. There are five cases where the Committee indicated a tightening of policy, but did not endorse it in the following meeting. On three occasions, an easing in policy was announced but the target rate remained unchanged in the next meeting. On $18^{\text {th }}$ March 2003 (denoted with “*” in the table), the press statement did not contain a balance of risk assessment, since the FOMC felt that the geopolitical situation was too uncertain.

Table 2 lists the relationship between press releases and subsequent policy action between August 2003 and October 2006. The last column states whether the announcement was consistent with the action. ${ }^{2}$ The results in Table 2 show that there were no occasions where the FOMC changed policy direction from what was announced in the previous meeting, though we do find two recent occasions where the FOMC indicated that its action in the following meetings was to depend on incoming economic information. However, as a glance at Figure 1 shows, market agents seem to have anticipated the policy decisions without any apparent problems.

\footnotetext{
${ }^{2}$ In the table, 'no change' signifies the FOMC statement '...in these circumstances, the Committee believes that policy accommodation can be maintained for a considerable period'. After a few months of policy inaction the FOMC began to change its wording to ' . ... the Committee believes that it can be patient in removing its policy accommodation', which we have described as as 'not yet' in the table. This was followed by statements containing the sentence '... the Committee believes that policy accommodation can be removed at a pace that is likely to be measured', which we have interpreted as 'Yes, 25 bp'. While the federal funds rate rose from meeting to meeting by $25 \mathrm{bp}$, the wording was changed on $13^{\text {th }}$ December 2005 to 'The Committee judges that some further measured policy firming is likely to be needed to keep the risks to the attainment of both sustainable economic growth and price stability roughly in balance' and interest rate rises continued to the following meetings. 'Yes/No' refers to the following two formulations: ' ...the Committee judges that some further policy firming may yet be needed to address inflation risks but emphasizes that the extent and timing of any such firming will depend importantly on the evolution of the economic outlook as implied by incoming information' $\left(10^{\text {th }}\right.$ May 2006), and 'The extent and timing of any additional firming that may be needed to address these risks will depend on the evolution of the outlook for both inflation and economic growth, as implied by incoming information.' (29 $9^{\text {th }}$ June 2006).
} 
Table 2: FOMC statements and subsequent policy actions, since 2003

\begin{tabular}{|c|c|c|c|}
\hline Date & $\begin{array}{l}\text { Announcement } \\
\text { for next meeting } \\
\text { (and beyond) }\end{array}$ & $\begin{array}{l}\text { Action next } \\
\text { meeting }\end{array}$ & As announced? \\
\hline 12.8 .2003 & No change & 0 & Yes \\
\hline 16.9 .2003 & No change & 0 & yes \\
\hline 28.10 .2003 & No change & 0 & yes \\
\hline 9.12 .2003 & No change & 0 & yes \\
\hline 28.1 .2004 & Not yet & 0 & yes \\
\hline 16.3 .2004 & Not yet & 0 & yes \\
\hline 4.5 .2004 & Yes, 25bsp & $+25 \mathrm{bsp}$ & yes \\
\hline 30.6 .2004 & Yes, 25bsp & $+25 \mathrm{bsp}$ & yes \\
\hline 10.8 .2004 & Yes, 25bsp & +25bsp & yes \\
\hline 21.9.2004 & Yes, 25bsp & +25bsp & yes \\
\hline 10.11 .2004 & Yes,25bsp & $+25 \mathrm{bsp}$ & yes \\
\hline 14.12 .2004 & Yes,25bsp & $+25 \mathrm{bsp}$ & yes \\
\hline 2.2 .2005 & Yes, 25bsp & $+25 \mathrm{bsp}$ & yes \\
\hline 22.3.2005 & Yes, 25bsp & +25bsp & yes \\
\hline 3.5.2005 & Yes,25bsp & $+25 \mathrm{bsp}$ & yes \\
\hline 30.6 .2005 & Yes, 25bsp & $+25 \mathrm{bsp}$ & yes \\
\hline 9.8.2005 & Yes, 25bsp & $+25 \mathrm{bsp}$ & yes \\
\hline 20.9 .2005 & Yes, 25bsp & +25bsp & yes \\
\hline 1.11 .2005 & Yes, 25bsp & $+25 b s p$ & yes \\
\hline 13.12.2005 & Yes, 25bsp & $+25 \mathrm{bsp}$ & yes \\
\hline 31.1 .2006 & Yes, 25bsp & $+25 \mathrm{bsp}$ & yes \\
\hline 28.3 .2006 & Yes, 25bsp & $+25 b s p$ & yes \\
\hline 10.5.2006* & Yes/No & $+25 b s p$ & Yes/no \\
\hline 29.6.2006* & Yes/No & 0 & Yes/no \\
\hline 8.8.2006 & No change & 0 & yes \\
\hline 20.9 .2006 & No change & 0 & yes \\
\hline 25.10 .2006 & Yes/no ${ }^{3}$ & 0 & \\
\hline
\end{tabular}

In this section we discuss whether the regime switch to providing information at an earlier stage for a period covering the next and meetings beyond the next, has reduced market rate volatility. We saw previously that markets appear to react to central bank talk, and that FOMC directions are followed up in the ensuing meeting. Since that seems to be the case, and since the previous section showed that surprises in policy moves on the day of FOMC announcements have been very low and have not changed since 1994, we examine the hypothesis whether the there is lower volatility of forward rates between FOMC meetings during the two regimes in comparison to the period before 1999. Why should this be the case? If agents know after a FOMC meeting the policy intentions of the central bank for the subsequent meeting, or, even subsequent meetings, market agents can adjust money market rates with less error and thus reduce interest rate volatility.

The reasoning is as follows. Imagine a central bank which meets every 40 days (for simplicity). On day $t=1$ it confirms the existing official rate (say 4 per cent) and simultaneously

\footnotetext{
3 “The extent and timing of any additional firming ... will depend on the evolution of the outlook for both inflation and economic growth, as implied by incoming information” (Press statement, October 2006)
} 
releases its outlook which uses official language to hint at a rise at the next meeting, $t=40$, of 25 bp. If the bank's release is believed, then the price of a one month's (= 30 days) currency contract for purchase one month ahead, must reflect the expected rise at $t=40$. For example, suppose (in the case of the USA) we were looking to buy a one month federal funds ('FF') contract to start in one month's time ('one month forward, for one month') immediately after the announcement on $t=1$. We would be buying a contract which would run from $t=31$ to $t=61$ and during that period it would pay nine days $(=40-31)$ at 4 per cent and 21 days $(=61-40)$ days at 4.25 per cent. The corresponding contract (still 'one month forward, for one month') priced the following day, $t=2$, would deliver eight days at 4 per cent and 22 days at 4.25 per cent. And so on. The interest paid on the contract would be a continually changing weighted average of the two interest rates, where the weights would be the term of the contract before the next Fed meeting and the term afterwards.

Figures 3 and 4 should be viewed in this light. They show the actual movement in forward rates during the two Fed disclosure regimes, as discussed above. Both figures show the development of the 1-month forward rate from a few days before a meeting when the federal funds target rate was not changed (the date is denoted by $\mathrm{t}=0$ and the first vertical line) until a few days after the second meeting (denoted by the vertical line on the right), when the target rate was increased in both cases by 25 bp. ${ }^{4}$ Figure 3 shows the movement of the market rate in anticipation of the policy rate increase in May 1997 and Figure 4 depicts the market rate movement under the new disclosure regime when the Committee raised the rate in June 2004. Both market rates rise over time in anticipation of the expected policy rate rise. However, the market rate movement between meetings in 1997 is more erratic with periods in which it falls and shows various jumps, before it increases more steadily. When we compare the movement of the rate between announcements in 2004, the rate movement looks almost like a straight, upward sloping line, which is what we would expect on the basis of the previous discussion.

\footnotetext{
${ }^{4}$ Both figures are scaled to the maximum of 30 at the end of the scale.
} 
Figure 3: Forward rate movement prior to increase in March 1997

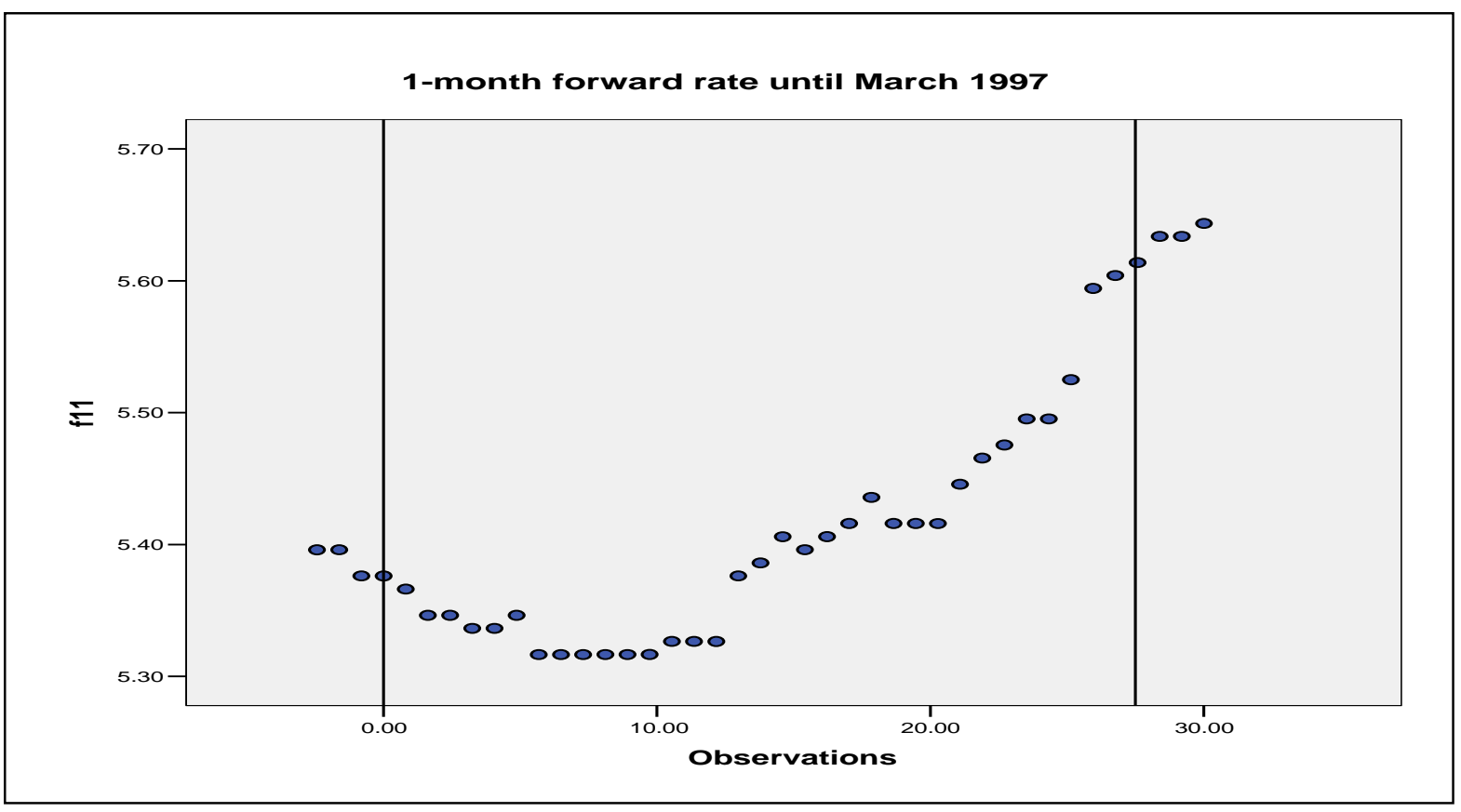

Figure 4: Forward rate movement prior to increase in June 2004

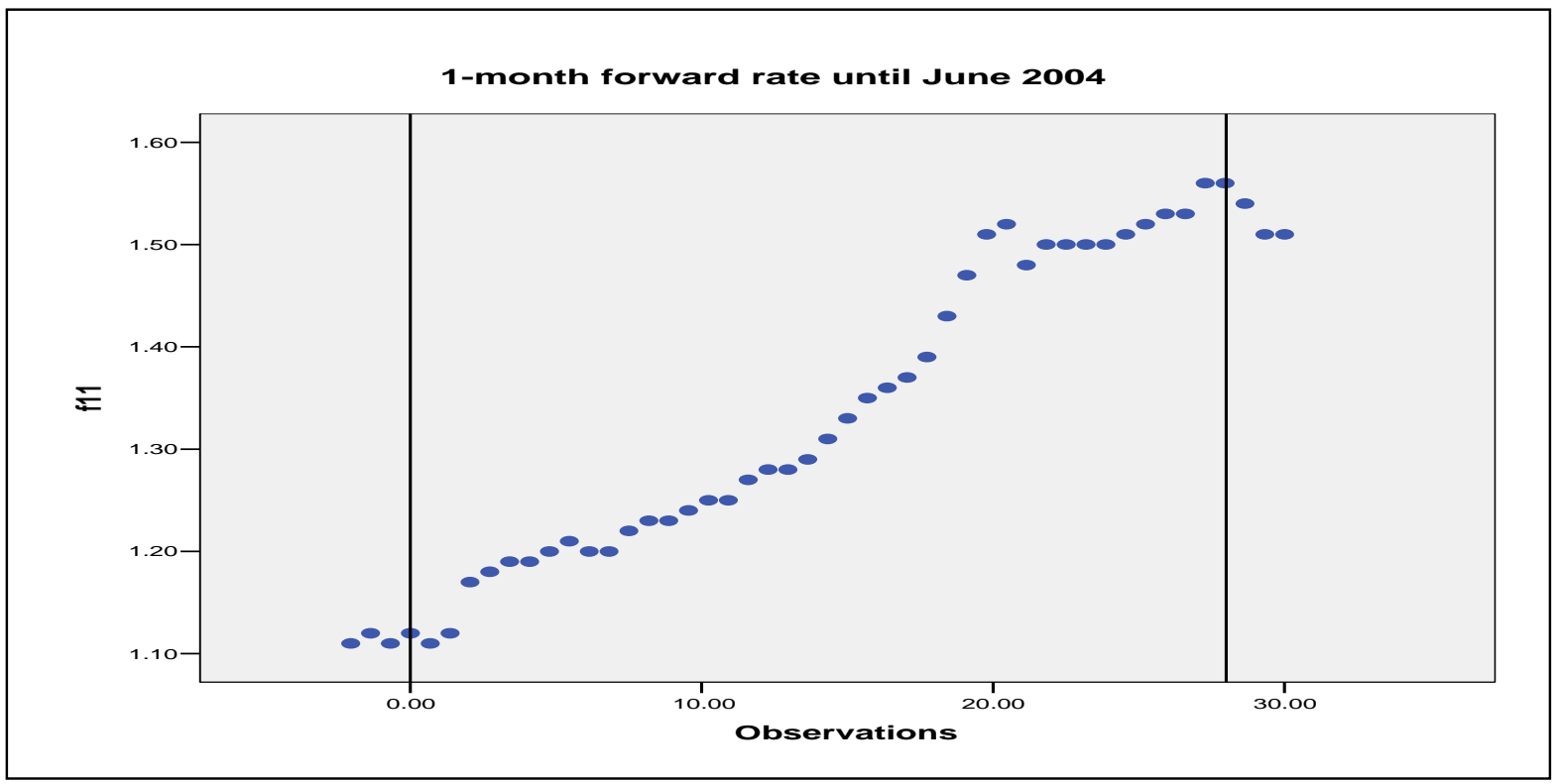

These graphs can only be regarded as illustrative since each represents a snapshot of two inter-meeting period in the pre- and post- Fed communication change. Allowing for all sample observations (see Figure 5), we find that volatility is comparatively lower in the period since 2001. This may support the view that when agents adjust rates 
gradually and smoothly in anticipation of a future rate change, we expect a fall in market rate volatility.

Figure 5: Volatility of the forward rate measured as the squared change

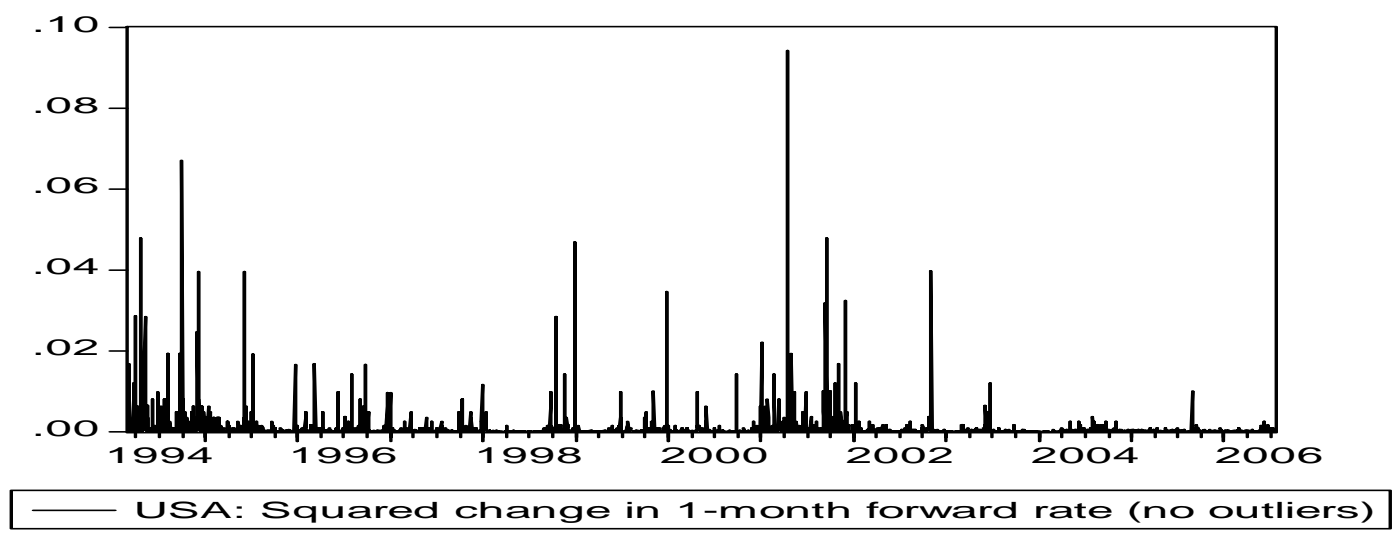

\section{The EGARCH model}

We test the hypotheses that changes in disclosure practice in 2000 and 2003 (by reducing uncertainty) have increased dependence between previous and current changes in the market rate by allowing for with the disclosure regime varying effects on the first lag of the dependent variable. The hypothesis is that current interest rate changes depend more strongly on previous ones in the later periods than in the pre-2000 period (see section 3). Further, in the previous section, we pointed out that particularly in the period since 2003, volatility in market rates between meetings has fallen. We test two hypotheses. Firstly, it is generally expected that 'news' increases interest rate volatility (Chadha and Nolan, Kohn and Sack....). Since we examine the short end of the yield curve, 'news' is measured by central bank communication such as speeches and other central bank releases. ${ }^{5}$ If the 'balance-of-risk' statement and the interest rate prediction of the FOMC for the next meeting contains 'all' short-term relevant information, then we expect that the effect of releases of other Fed communication in the pre-2000 period is higher than in the following two periods. In other words, we expect that communication news induces less volatility in the post-2000 than pre-2000 period.

\footnotetext{
${ }^{5}$ Fleming and Remolan (1999) find that macroeconomic announcement surprises are relatively weak for short maturities and stronger for intermediate maturities. Haldane and Read (2000) also point out that macroeconomic announcement effects may induce hump-shaped responses with sharper yield changes for intermediate maturities than shorter ones. This is also a rather intuitive result. Central banks tend to change interest rates gradually in response to relevant macroeconomic surprises, thus creating a monetary policy cycle of tightening or easing. Consequently, macroeconomic news is important for agents' prediction of the entire monetary policy cycle when long-term instruments are concerned. However, agents may ignore the Fed's ultimate target rate (deduced from economic surprises), when only short-term instruments are considered.
} 
We begin with testing for the effect of the change in disclosure regimes by employing an exponential GARCH (EGARCH) model. The conditional mean equations for the changes in market rates are explained by policy rate surprises $\Delta$ polsur $r_{t}$, and two dummy variable $D_{1 t}$ and $D_{2 t}$ interacting with first lags of the dependent variable. The dummy variable $D_{1 t}$ has the value 1 between January 2000 and $11^{\text {th }}$ August 2003 and, $D_{2 t}$ is after $11^{\text {th }}$ August 2003 and is zero otherwise.

$$
\Delta r_{t, j}=\alpha+\beta_{1} D_{1 t} \Delta r_{t-1, j}+\beta_{2} D_{2 t} \Delta r_{t-1, j}+\beta_{3}\left(1-D_{1 t}-D_{2 t}\right) \Delta r_{t-1, j}+\beta_{4} \Delta \text { polsur }_{t}+\beta_{5 i} \sum D a y_{t i}+\beta_{6 i} \sum D u_{t i}+\varepsilon_{t, j}(1)
$$

The dependent variables are daily changes in CD forward rates at maturities $(j)$ of 1,3 , and 6 months and the variable Dout $_{t}$ is a 1-0 dummy variable to account for two outliers. The coefficient $\beta_{4}$ measures agents' degree of surprise of FOMC policy on the day of announcement. Further, we distinguish between lagged effects of forward rate changes in the pre- $2000\left(\beta_{3}\right), 2000$ to $2003\left(\beta_{1}\right)$ and post August $2003\left(\beta_{2}\right)$ regimes. The aim is to test the hypothesis that in the second and third period, inertia is higher compared to the early period. This should be so when markets adjust rates more gradually than before the regime change, in which case $\beta_{3}<\beta_{1}$ and $\beta_{3}<\beta_{2}$. Additionally, day of the week effects are included in the variable Day.

The conditional variance of the exponential GARCH (EGARCH) model is:

$$
\log \sigma_{t}^{2}=\omega+\chi \log \sigma_{t-1}^{2}+\delta\left|\frac{\varepsilon_{t-1}}{\sigma_{t-1}}\right|+\theta \frac{\varepsilon_{t-1}}{\sigma_{t-1}}+\phi_{1 i} \sum_{i=1}^{3} D_{t i} \text { Com }_{t}+\lambda_{1} \text { DSept }_{t}+\lambda_{2 i} \sum \text { Day }_{t i} \text { (2) }
$$

The logarithmic formulation implies that the conditional variance $\sigma_{t}^{2}$ is always non-negative, regardless of the possible negative parameter values. The innovations $\varepsilon_{t}$, are divided by the standard deviation of the conditional variance, resulting in standardized shocks, so that the effect of these terms depends on their relative size. The coefficient $\theta$ measures the existence of an asymmetric impact if $\theta$ differs from zero. The coefficient $\chi$ measures the degree of volatility persistence. All communication variables $\mathrm{com}_{t}$ are dummy variables which take the value one when central bank communication occurs and are zero otherwise. The variable com $_{t}$ summarises various forms of Fed communication. It accounts for speeches given by the chairman of the Board of Govenors and releases of the Monetary Policy Report to Congress (formerly the Humphrey-Hawkins Testimony to Congress). These are semi-annual reports delivered in 
February and July where the chairman of the Board of Govenors of the Fed reports the basic state of the US economy. The report consists of two sections, with the first section summarising past policy decisions and their impact on the economy and the second section focusing on recent financial and economic developments. It is expected that both channels of communication have a positive impact on volatility. Further, communication includes also hearings on economic outlook, minutes of Board discount rate meetings, releases of the Minutes of the Federal Open Market Committee and other monetary announcements as well as all other testimony by the chairman before the Senate and the House Budget Committees. ${ }^{6}$ The dummy variable $D_{t 3}$ is defined as $D_{t 3}=\left(1-D_{t 1}-D_{t 2}\right)$. Furthermore, we included an impulse dummy variable accounting for increased volatility on $11^{\text {th }}$ September 2001 and a few days thereafter $\left(D S e p t_{t}\right)$.

The main interest lies in the coefficients $\phi_{i 1}$, which measure the effect of news communication (other than FOMC statements after the meetings) on market rate volatility. It is expected that volatility rises in response to news releases by members of the FOMC, but volatility should respond less to Committee news releases during the two disclosure periods compared to the earlier period. We expect the latter two coefficients to be positive and have comparably lower values for the two periods since 2000 .

Tables 3 and 4 show the results of the mean and conditional volatility estimations, where we included Fed communication in the variance equation.

Throughout the maturity spectrum there is greater inertia over the period 2000 and 2003 than in the earlier period. But, for the shortest maturity, we find significant inertia in the later disclosure period, too. We will turn to the difference in the coefficients when we discuss table 5, below. There are no remaining ARCH effects and with the exception of the third equation, the explanatory power is reasonable

\footnotetext{
${ }^{6}$ Data are from www.federalreserve.gov/boarddocs/
} 
Table 3: The estimation results of the mean equation (1):

\begin{tabular}{|l|l|l|l|}
\hline & $\begin{array}{l}\Delta r_{t, j} \\
(\mathrm{j}=1)\end{array}$ & $\begin{array}{l}\Delta f r_{t, j} \\
(\mathrm{j}=3)\end{array}$ & $\begin{array}{l}\Delta f r_{t, j} \\
(\mathrm{j}=6)\end{array}$ \\
\hline$\alpha$ & $0.0025^{* * *}$ & $0.0020^{* * *}$ & $0.0020^{* * *}$ \\
& $(0.000)$ & $(0.000)$ & $(0.005)$ \\
\hline$\Delta f r_{t-1, j}$ pre- 2000 & 0.0463 & 0.0355 & -0.0155 \\
& $(0.173)$ & $(0.257)$ & $(0.701)$ \\
\hline$\Delta f r_{t-1, j}$ first change & $0.1665^{* * *}$ & $0.1191^{* * *}$ & $0.1230^{* * *}$ \\
& $(0.000)$ & $(0.000)$ & $(0.002)$ \\
\hline$\Delta f r_{t-1, j}$ second & $0.0833^{* *}$ & 0.0403 & 0.0113 \\
change & $(0.040)$ & $(0.365)$ & $(0.781)$ \\
\hline polsur $r_{t}$ & $0.5688^{* * *}$ & $0.485^{* * *}$ & $0.4059 * *$ \\
& $(0.000)$ & $(0.000)$ & $(0.014)$ \\
\hline$R^{2}$ & 0.202 & 0.221 & 0.037 \\
\hline F-statistic & $18.36^{* * *}$ & $23.28^{* * *}$ & $2.67 * * *$ \\
& $(0.000)$ & $(0.000)$ & $(0.000)$ \\
\hline ARCHLM(15) & 9.69 & 8.06 & 9.79 \\
& $(0.839)$ & $(0.922)$ & $(0.833)$ \\
\hline
\end{tabular}

The estimated coefficients for outlier dummies and day effects are not reported here. The values in brackets under the estimated coefficients and diagnostics are the probability levels. For ease of reading, '*' indicates significant at less than $10 \%$, '**' at less than $5 \%$ and ' $* * *$ ' at less than $1 \%$. 'first change' refers to the period 2000-August 2003 and 'second change' refers to the period since August 2003.

Table 4: Estimation results of the effect of communication in the conditional volatility equation:

\begin{tabular}{|c|c|c|c|c|c|c|c|c|c|}
\hline & \multicolumn{3}{|l|}{$\begin{array}{r}\Delta f r_{t, j} \\
(j=1)\end{array}$} & \multicolumn{3}{|l|}{$\begin{array}{r}\Delta f r_{t, j} \\
(\mathrm{j}=3)\end{array}$} & \multicolumn{3}{|l|}{$\begin{array}{l}\Delta f r_{t, j} \\
(\mathrm{j}=6)\end{array}$} \\
\hline & before & first & second & before & first & second & before & first & second \\
\hline speech & $\begin{array}{l}-0.251 \\
* * *\end{array}$ & $\begin{array}{l}0.367 \\
* * *\end{array}$ & $\begin{array}{l}-0.121 \\
*\end{array}$ & $\begin{array}{l}0.168 \\
* * *\end{array}$ & $\begin{array}{l}0.456 \\
* * *\end{array}$ & 0.065 & $\begin{array}{l}0.098 \\
* *\end{array}$ & $\begin{array}{l}0.198 \\
* * *\end{array}$ & $\begin{array}{l}0.129 \\
* *\end{array}$ \\
\hline testimony & -0.245 & 0.050 & -0.202 & $\begin{array}{l}0.483 \\
* * *\end{array}$ & $\begin{array}{l}0.400 \\
* * *\end{array}$ & $\begin{array}{l}0.458 \\
* * *\end{array}$ & $\begin{array}{l}0.510 \\
* * *\end{array}$ & 0.178 & $\begin{array}{l}0.426 \\
* * \\
\end{array}$ \\
\hline econout & $\begin{array}{l}1.025 \\
* * *\end{array}$ & $\begin{array}{l}-0.987 \\
* * *\end{array}$ & 0.144 & $\begin{array}{l}0.812 \\
* * *\end{array}$ & -0.271 & 0.331 & $\begin{array}{l}1.438 \\
* * *\end{array}$ & -0.084 & $\begin{array}{l}0.468 \\
* *\end{array}$ \\
\hline disc & N/A & $\begin{array}{l}-0.512 \\
* * *\end{array}$ & $\begin{array}{l}-0.407 \\
* * * \\
\end{array}$ & N/A & $\begin{array}{l}-0.637 \\
* * *\end{array}$ & $\begin{array}{l}-0.418 \\
* * *\end{array}$ & N/A & -0.031 & -0.181 \\
\hline $\min$ & $\begin{array}{l}0.762 \\
* * *\end{array}$ & -0.094 & $\begin{array}{l}0.388 \\
* * *\end{array}$ & $\begin{array}{l}0.266 \\
* * *\end{array}$ & $\begin{array}{l}0.265 \\
* * *\end{array}$ & $\begin{array}{l}0.381 \\
* * *\end{array}$ & $\begin{array}{l}-0.309 \\
* * *\end{array}$ & $\begin{array}{l}0.244 \\
* *\end{array}$ & $\begin{array}{l}-0.232 \\
*\end{array}$ \\
\hline other & \multicolumn{3}{|c|}{$-0.448 * * *$} & \multicolumn{3}{|c|}{$-0.410 * * *$} & \multicolumn{3}{|c|}{$-0.175 * *$} \\
\hline
\end{tabular}

The estimated coefficients for outlier dummies are not reported here. For ease of reading, '*' indicates significant at less than $10 \%$, ' $* *$ ' at less than $5 \%$ and '***' at less than $1 \%$. Note: We included a dummy variable to account for the rise in volatility on and shortly after $11^{\text {th }}$ September 2001 . N/A indicates no data availability.

The results of the conditional volatility are presented in Table 4. In the columns of Table 4, 'before' refers to the period 1997-2000, 'first' covers the period 2000-2003, and 'second' is the 
period from August 2003 until mid-July 2006. The variable 'speech' refers to speeches made by the chairman of the Board, 'testimony' is the release of the Monetary Policy Report to Congress, 'econout' stands for economic outlook, 'disc' is for Minutes of Board discount rate meeting, ' $m i n$ ' stands for the release of the minutes of the FOMC and the variable 'other' denotes other monetary announcements. The latter were rather few and were not split over the three regimes. The results of the conditional volatility estimates show that the various forms of Fed communications are overwhelmingly significant. All forms of communication show significant coefficients over all maturities, with the exception of the Testimony to Congress variable, which is insignificant with respect to the shortest maturity.

Our main interest lies in finding out whether the changes in statements after the FOMC meetings affected (i) market participants' pricing behaviour, shown in the degree of inertia, and (ii) the news value of other Fed communications. Table 5 shows the results of Wald tests for the equality of the coefficients of the lagged dependent variables over the three periods (inertia from the mean equation) and the communication coefficients (in the volatility equation).

Table 5: Test results on the equality of coefficients in the three regimes:

\begin{tabular}{|c|c|c|c|c|c|c|c|c|c|c|c|c|}
\hline & \multicolumn{4}{|c|}{$\begin{array}{l}\Delta f r_{t, j} \\
(\mathrm{j}=1)\end{array}$} & \multicolumn{4}{|c|}{$\begin{array}{l}\Delta f r_{t, j} \\
(\mathrm{j}=3)\end{array}$} & \multicolumn{4}{|c|}{$\begin{array}{l}\Delta f r_{t, j} \\
(\mathrm{j}=6)\end{array}$} \\
\hline & All & $\mathrm{B}=\mathrm{F}$ & $\mathrm{B}=\mathrm{S}$ & $\mathrm{F}=\mathrm{S}$ & All & $\mathrm{B}=\mathrm{F}$ & $\mathrm{B}=\mathrm{S}$ & $\mathrm{F}=\mathrm{S}$ & All & $\mathrm{B}=\mathrm{F}$ & $\mathrm{B}=\mathrm{S}$ & $\mathrm{F}=\mathrm{S}$ \\
\hline lags & $* * *$ & $* * *$ & no & $*$ & $*$ & $* *$ & no & no & $* *$ & $* * *$ & no & $* *$ \\
\hline speech & $* * *$ & $* * *$ & * & $* * *$ & $* * *$ & $* * *$ & no & $* * *$ & no & no & no & no \\
\hline testimony & no & no & no & no & no & no & no & no & no & no & no & no \\
\hline econout & $* * *$ & $* * *$ & $* * *$ & $* * *$ & $* *$ & $* * *$ & no & $* *$ & $* * *$ & $* * *$ & $* * *$ & $* *$ \\
\hline disc & N/A & N/A & N/A & no & no & no & no & no & N/A & N/A & N/A & no \\
\hline $\min$ & $* * *$ & $* * *$ & $* * *$ & $* * *$ & no & no & no & no & $* * *$ & $* * *$ & no & $* * *$ \\
\hline
\end{tabular}

The estimated coefficients for outlier dummies are not reported here. For ease of reading, '*' indicates significant at less than $10 \%$, '**' at less than $5 \%$ and '***' at less than $1 \%$ and 'no' stands for insignificant

The column with the heading 'All' shows the test result of the null hypothesis of all coefficients being equal to zero. The notation ' $B=F$ ' indicates that we test for equality of the coefficients for the first (pre-2000) and the second (2000-2003) period, ' $B=S$ ' stand for testing coefficient equality for pre2000 and post-2003 period, and, finally, ' $F=S$ ' compares coefficients of the last two periods. 'lags' refers to the first lag of the dependent variable in the mean equation. ${ }^{7}$ Turning to the first row and the shortest maturity, the test results show that coefficients differ between the three periods ('All'). This difference is mostly due to the difference in coefficients between the first and the second regime (' $\mathrm{B}=\mathrm{F}$ '). There is no significant difference between the coefficients of the last and the first regime (' $\mathrm{B}=\mathrm{S}$ '), but a significant difference between the first and the second regime (' $\mathrm{F}=\mathrm{S}$ '). All tests indicate that the inertia effects

\footnotetext{
${ }^{7}$ With reference to Table 4, $B$ is shortened for 'before', $F$ is short-form of 'first' regime and $S$ stands for 'second' regime.
} 
discussed before are only present in the period between 2000 and 2003, but not in any of the other periods. This result is similar over all maturities. We find differences in coefficients between the three regimes, but not as we had expected in that inertia is highest during the last or the last two regimes. Turning to the communication variables and their differences over the three regimes, we find that most of the differences between regimes are found at the shortest maturity and the least at the longest maturity. Notably, the news content of the economic outlook has changed between regimes over all maturities. Speeches by the chairman of the Board have distinct impacts over the tree regimes on the two shorter maturities. In general, there is evidence that other than statement communication by the Fed has had different effects on volatility during the three regimes. We expected that the news content of Fed communication (other than press statement) did not only differ between regimes, but that, if the communication in the statements after the FOMC meeting has become more effective over time, that the impact of other Fed communication on market rate volatility would be less over time. This result does not hold. ${ }^{8}$

\section{Summary and conclusion}

The FOMC changed its press statements after its meetings by releasing forward-looking information and, most recently, by releasing information of near-term policy implications. The release of this type of information should reduce uncertainty about the near-future policy rate changes. This should impact on inter-meeting volatility in short-term market rates.

We began by looking at the impact of this information release on market agents' expectations. In line with other studies, we found that on the day of the meeting, market rates were well anticipated.

The novelty of the paper is to consider the effect of the news release on the inter-meeting period. We examine both, the effect on the market rate change and the volatility of the market rate, using an EGARCH model. We find that there is some evidence that adjustment is smoother in the 'balance-of-risk' period than in any other period. Further, there is evidence that other Fed communication impacts mostly on the very short end of the yield curve. Further, this communication affects volatility differently under the different regimes. Most important seem to be speeches by the chairman and releases on economic outlook.

\footnotetext{
${ }^{8}$ There is no reason to assume that central bank communication should only affect volatility and not the mean market rates. We used an absolute equation similar to that by Lewis and.... However, the results were not very informative.
} 


\section{References}

Chortareas, G. Stasavage, D. and Sterne, G. (2003) Does Monetary Policy Transparency Reduce Disinflation Costs? Manchester School, 71 (5), September, 521-40.

Connolly, E and M Kohler (2004) 'News and interest rate expectations: a study of six central banks’, Economic Group Reserve Bank of Australia, Research discussion paper 2004-10.

Coppell J and Connolly J (2003), 'What Do Financial Market Data Tell Us About Monetary Policy Transparency,’ Reserve Bank of Australia, Research Discussion Paper 2003/05.

Demiralp, S and O Jorda (2004) 'The response of term rates to Fed announcements', Journal of Money, Banking and Credit, 36, 3, 387-405.

Federal Reserve Board (2000) 'Modifications to the FOMC’s Disclosure Procedures', http://www.federalreserve.gov/boarddocs/press/general/2000/20000119/attachment.pdf

Federal Reserve Press Release, $20^{\text {th }}$ March 2001

http://www.federalreserve.gov/boarddocs/press/monetary/2001/20012003/default.htm

Federal Reserve Press Release, $12^{\text {th }}$ August 2003

http://www.federalreserve.gov/boarddocs/press/monetary/2003/20030812/default.htm

Federal Reserve Press Release, $28^{\text {th }}$ January 2004

http://www.federalreserve.gov/boarddocs/press/monetary/2004/20040128/default.htm

Federal Reserve Press Release, $4^{\text {th }}$ May 2004

http://www.federalreserve.gov/boarddocs/press/monetary/2004/20040504/default.htm

Federal Reserve Press Release, 31 $31^{\text {st }}$ January 2006

http://www.federalreserve.gov/boarddocs/press/monetary/2006/20060131/default.htm

Federal Reserve Press Release, $13^{\text {th }}$ December 2005

http://www.federalreserve.gov/boarddocs/press/monetary/2005/20051213/default.htm

Haldane, A. G. and Read, V. (2000) Monetary Policy Surprises and the Yield Curve. Bank of England Working Paper no. 102.

Hardy, D C (1998) Anticipation and surprises in central bank interest rate policy: The case of the Bundesbank, IMF working paper 98/43

King, M. (1997) The Inflation Target Five Years On. Bank of England Quarterly Bulletin, 37 (4), 431-42.

Kohn, D L and B P Sack (2003) 'Central Bank talk: Does it matter and why?' in Macroeconomics, Monetary Policy and Financial Stability. Ottawa: Bank of Canada.

Kuttner, K. N. (2001) Monetary Policy Surprises and Interest Rates: Evidence from the Fed Funds Futures Market. Journal of Monetary Economics, June 2001, 47 (3), 523-44. 
Lange, J, Sack, B and W Whitesell (2003) 'Anticipation of monetary policy in financial markets', Journal of Money, Credit, and Banking, 35,6, 889-909. CHECk

Poole, W and R H Rasche (2000) 'Perfecting the market's knowledge of monetary policy', Federal Reserve Bank of St Louis working paper 2000-010A, http://research.stlouisfed.org/wp/2000/2000-010.pdf

Poole, W. Rasche, R. H. and Thornton D. L. (2002) Market Anticipations of Monetary Policy Actions. The Federal Reserve Bank of St Louis Review, 84(4), 65-94.

Ross K (2002) 'Market Predictability of ECB Monetary Policy Decisions: A Comparative Examination’, IMF Working Paper no. 02/233. 